\title{
Post-treatment persistent alpha-fetoprotein elevation in a patient with testicular cancer
}

\author{
Pretrvávajúca elevácia alfa-fetoproteínu u pacienta po liečbe \\ nádoru semenníka
}

\author{
Fedorkova L. ${ }^{1,2}$, Ondrus D. ${ }^{1}$ \\ $11^{\text {st }}$ Department of Oncology, Comenius University, Faculty of Medicine \& St. Elisabeth Cancer Institute, Bratislava, Slovakia \\ ${ }^{2}$ Department of Medical Oncology, St. Elisabeth Cancer Institute, Bratislava, Slovakia
}

\begin{abstract}
Summary
Background: Persistent alpha-fetoprotein elevation in a patient following orchiectomy and chemotherapy for non-seminomatous testicular germ cell tumor is a rare condition when persistence of the tumor and false positivity of tumor marker elevation has to be differentiated. This situation often leads to over-treatment and potential toxicity with adverse events which can be severe. Case: A case of a patient with the abovementioned disease and course of treatment is presented. As no radiological signs of the disease were present and the level of alpha-fetoprotein was mild and stable, the tumor marker elevation was evaluated as false positive. Possible causes of the tumor marker elevation were identified as other serious diseases are known to cause such a false positivity. The level of alpha-fetoprotein remained unchanged despite alcohol abstinence and hepatoprotective treatment by silymarin. Hepatitis B and C serological tests were negative, and no other malignant tumor was identified. Finding of terminal ileum circular wall thickening and stratification with a reaction of surrounding visceral fat and lymph nodes persisting in CT scans suggests the presence of inflammatory bowel disease, possibly explaining the alpha-fetoprotein elevation. The patient has no evidence of the disease more than 14 months after the end of chemotherapy treatment with no change in the elevation of alpha-fetoprotein. Conclusion: After the treatment, when no other indication of testicular cancer than an elevated alpha-fetoprotein level is present, the patient should be managed by ongoing surveillance.
\end{abstract}

\section{Key words}

alpha-fetoprotein - tumor markers - testicular tumors - chemotherapy
The authors declare they have no potential conflicts of interest concerning drugs, products, or services used in the study.

Autor̆i deklarují, že $v$ souvislosti s predmětem studie nemaji žádné komerční zájmy.

The Editorial Board declares that the manuscript met the ICMJE recommendation for biomedical papers.

Redakční rada potvrzuje, že rukopis práce splnil ICMJE kritéria pro publikace zasílané do biomedicínských časopisů.

Lucia Fedorkova, MD

$1^{\text {st }}$ Department of Oncology,

Comenius University,

Faculty of Medicine

St. Elisabeth Cancer Institute

Heydukova 10

81250 Bratislava

Slovakia

lucia.nocarova@ousa.sk

Submitted/ Obdŕžané: 13. 11. 2020 Accepted/Prijaté: 5. 1. 2021

doi: $10.48095 /$ ccko202156 


\begin{abstract}
Súhrn
Východiská: Pretrvávanie zvýšenej hladiny alfa-fetoproteínu u pacienta s neseminómovým germinatívnym tumorom semenníka po orchiektómii a chemoterapii je výnimočný stav, kedy je potrebné odlísit pretrvávanie nádoru od falošnej pozitivity onkomarkera. Táto situácia často vedie k nadliečeniu pacienta, čo môže spôsobit závažnú akútnu aj neskorú toxicitu a iné komplikácie spojené s liečbou. Prípad: Prezentujeme prípad pacienta s vyššie uvedeným ochorením a priebehom liečby. Vzhladom na to, že pretrvávanie ochorenia nebolo rádiologicky dokázané a hladina alfa-fetoproteínu bola mierne stabilne zvýšená, bol zvýšený onkomarker vyhodnotený ako falošne pozitívny. Možné príčiny zvýšenej hodnoty onkomarkera boli analyzované, kedže môže byt’ markerom aj iných závažných ochorení. Hladina alfa-fetoproteínu sa nezmenila ani pri abstinencii od alkoholu, ani pri podávaní hepatoprotektívnej liečby silymarínom. Sérológické testy hepatitíd B a C boli negatívne. Iný malígny tumor nebol identifikovaný. Na CT bolo nájdené zhrubnutie a stratifikácia cirkulárnej steny terminálneho ilea a reakcia okolitého viscerálneho tuku a lymfatických uzlín, ktoré pripomína nešpecifické zápaly čreva, ktoré by mohli vysvetlovat vyššiu hladinu alfa-fetoproteínu. Viac ako 14 mesiacov po ukončení liečby chemoterapiou pacient nemá žiaden dôkaz aktivity ochorenia, hladina alfa-fetoproteínu pretrváva nezmenená. Záver: Ak nie je po ukončení liečby prítomný iný znak prítomnosti nádoru semenníka, ako zvýšený onkomarker, pacient by mal byṫ dalej prísne observovaný.
\end{abstract}

Klúčové slová

alfa-fetoproteín - onkomarkery - nádory semenníkov - chemoterapia

\section{Background}

Serum tumor markers (STM) play a key role in diagnosis, staging, management, prognosis and follow-up of testicular cancer [1-3]. However, the specificity of STM is limited and false positives can occur. Specifically, elevated alphafetoprotein (AFP) in adults can be associated with a variety of underlying processes [3-6].

With regard to germ cell tumors, AFP is primarily produced by yolk sac components and to a lesser extent by embryonal carcinomas and teratomas [7]. In one large cohort of nearly 1500 patients with testicular cancer, over $60 \%$ of patients with non-seminomatous germ cell testicular tumors (NSGCTTs) had elevated AFP levels, making it the most commonly elevated tumor marker in testicular cancer [8].

Other tumors, such as hepatocellular carcinoma, hepatoblastoma and gastric carcinomas, can cause AFP elevation. Hepatic cirrhosis, infectious hepatitis, alcohol-related liver disease are frequent non-malignant causes of AFP elevation. Rare causes of AFP elevation include Wilson's disease, hereditary tyrosinemia, ataxia teleangiectasia, Wiscott-Aldrich syndrome, hereditary alpha-fetoprotein persistency and inflammatory bowel disease [9-12]. Nicotine abuse can have synergistic effect to other causes of AFP elevation.

\section{Case}

A 39-year-old patient was admitted to our department to begin chemotherapy treatment after radical right-side inguinal orchiectomy.

Histopathological examination of the removed testis showed mixed NSGCTT composed of approximately equal parts of choriocarcinoma and yolk sac tumor and of diminutive areas of embryonal carcinoma.

Staging CT scan showed no signs of lymph node spread or distant metastases after the surgery. Non-specific nodules in lungs and terminal ileum circular wall thickening and stratification, with surrounding visceral fat reaction and slightly enlarged lymph nodes to $6-10 \mathrm{~mm}$ in the short axis, were evaluated by the radiologist as not-related to a germ cell tumor. MRI of the brain showed no signs of pathology.

At the time of the primary treatment (orchiectomy), STMs were elevated - AFP level was $356 \mathrm{IU} / \mathrm{mL}$ (normal $<7.5 \mathrm{IU} / \mathrm{mL}$ ) and human chorionic gonadotropin (hCG) level was 1,723 $\mathrm{mlU} / \mathrm{mL}$ (nor$\mathrm{mal}<2.6 \mathrm{mlU} / \mathrm{mL}$ )

At the time of patient's admission to our department (4 weeks later), the level of AFP was slightly elevated to $17.0 \mathrm{IU} / \mathrm{mL}$ (normal $<7.5 \mathrm{IU} / \mathrm{mL}$ ), levels of hCG, neuron-specific enolase (NSE) and lactate dehydrogenase (LDH) were in a normal range.

The stage of the disease was assessed to be T1N0M0 S1 - IS stage, meaning good prognosis NSGCTT. There were no signs of choriocarcinoma syndrome requiring special treatment [13].

Three cycles of chemotherapy (BEP regimen) were administered consider- ing the stage of the disease, according to European Society for Medical Oncology (ESMO), National Comprehensive Cancer Network (NCCN) and European Association of Urology (EAU) guidelines [14-16].

Administration of chemotherapy was well-tolerated by the patient, although he developed a peripherally inserted central catheter (PICC)-related thrombosis in the right basilic vein after the first cycle administration. Anticoagulant treatment by low-molecular-weight heparin was initiated.

STMs were examined repeatedly in the course of the treatment. hCG remained negative, AFP remained solidly elevated at a rate of no more than twice the normal value. The same result of STM levels was after the last cycle of chemotherapy and repeatedly in the course of regular follow-up (range 9.7-11.3 IU/mL).

After the end of the treatment, a CT scan repeatedly showed neither the signs of the disease spread nor persistent signs of inflammation in the ileocaecal region and stable benign-looking lung nodules. As there was no disease visible and the STM level was repeatedly the same with no significant increase or decrease, it was considered to be false positive.

The patient is under follow-up, currently with a disease-free survival of 14 months after the end of treatment.

\section{Results}

Initially mildly elevated AFP ( $<30 \mathrm{ng} / \mathrm{mL}$ ) is a rare condition, occurring in $1,7 \%$ of patients with testicular germ cell tumor [6]. 
The first dilemma in this patient's case was whether he should or should not undergo chemotherapy treatment. The NCCN guidelines do not advise to base decisions to treat solely on AFP values $<20 \mathrm{ng} / \mathrm{mL}$ [15]. The ESMO and EAU guidelines do not address this condition specifically. Such a patient is therefore managed as the one in IS stage. In this case, our decision was also made on the base of pre-orchiectomy high levels of STMs and non-specific lung nodules, possibly being metastases.

The second dilemma emerged after chemotherapy treatment, when AFP had not decreased to a normal value. The persisting very low rates of AFP and hCG elevation after the treatment of germ cell tumor may be explained by some few treatment failures or by the well-known low rate of false positive elevation of AFP and hCG in men without active germ cell tumor [17].

A patient with persistent AFP should undergo further examination to assess a possibility of persistence of cancer cells or presence of another serious disease causing AFP elevation. It is crucial to remember other malignant as well as benign possible causes of tumor marker mild elevation. As there was no sign of tumor (germ cell tumor or other tumor) on CT scan, other examination was conducted.

Hepatitis B and C serological tests were negative. Liver enzymes aspartate aminotransferase (AST), alanine aminotransferase (ALT) and gamma-glutamyl transferase (GMT) were initially elevated up to a 3-fold of the normal value. After hepatoprotective treatment by silymarin and alcohol abstinence, AST and ALT values decreased to a normal range and GMT to a 1.5-fold of the normal range; AFP level did not follow this decreasing trend.

The hypothesis of inflammatory bowel disease (IBD) being cause of AFP elevation was formed, based on $C T$ finding of terminal ileum circular wall thickening and stratification, with surrounding visceral fat reaction and enlarged lymph nodes and literature reporting correla- tion between IBD and mild AFP elevation [10]. The patient refused to undergo colonoscopy.

The most common causes are liver-related diseases and there are quite a number of cases with no identifiable etiology. However, in our patient's case, the IBD diagnosis seems more probable, supposedly Crohn's disease based on the location and radiological signs of the inflammation. According to Thompson et al [10] mild elevation of AFP was found in $9 \%$ of patients with ulcerative colitis and in 5\% of patients with Crohn's disease. As both incidence and prevalence of inflammatory bowel disease increases and is linked to a young age (as well as germ cell tumors are), we can expect more patients presenting both diagnoses and possibly false positive AFP elevation.

\section{Conclusion}

AFP mild elevation differential diagnostics can be misleading and, as this condition is rare and false positivity is little thought of, there is a risk of overtreatment, both primary - post-orchiectomy - and secondary - after chemotherapy administration. This could lead to potential short-term toxicity, such as febrile neutropenia, thrombocytopenia etc., long-term adverse effects, such as pneumotoxicity, secondary malignacy or infertility or to other events related to the treatment, such as a catheter-related infection or thrombosis (as our patient experienced).

This interference of other diseases makes these patients' follow-up harder. Their surveillance should be based rather on radiological than biochemical parameters.

We conclude that mildly elevated and stable AFP levels, when not accompanied by any other indication of testicular cancer, should be managed by ongoing surveillance. This would likely reduce unnecessary treatment, morbidity and cost.

\section{References}

1. Bartlett NL, Freiha FS, Torti FM. Serum markers in germ cell neoplasms. Heamatol Oncol Clin North Am 1991; 5(6) 1254-1260.
2. Talerman A, Haije WG, Baggerman L. Serum alphafetoprotein (AFP) in patients with germ cell tumors of the gonads and extragonadal sites: correlation between endodermal sinus (yolk sac) tumor and raised serum AFP. Cancer 1980; 46(2): 380-385. doi: 10.1002/1097-0142 (19800715)46:2<380::aid-cncr2820460228>3.0. co;2-u.

3. Gilligan TD, Seidenfeld J, Basch EM et al. American Society of Clinical Oncology Clinical Practice Guideline on uses of serum tumor markers in adult males with germ cell tumors. J Clin Oncol 2010; 28(20): 3388-3404. doi: 10.1200/JCO.2009.26.4481.

4. Albany C, Einhorn L. Pitfalls in management of patients with germ cell tumors and slight elevation of serum $\alpha$ fetoprotein. J Clin Oncol 2014; 32(19): 2114-2115. doi: 10.1200/JCO.2014.56.0607.

5. Schatte EC, Lerner SP. Re: Recognizing abnormal marker results that do not reflect disease in patients with germ cell tumors. J Urol 2000; 164(5): 1670

6. Wymer KM, Daneshmand S, Pierorazio PM et al. Mildly elevated serum alpha-fetoprotein (AFP) among patients with testicular cancer may not be associated with residual cancer or need for treatment. Ann Oncol 2017; 28(4): 899902. doi: 10.1093/annonc/mdx012.

7. Richie J, Steele G. Neoplasms of the testis. In: Wein AJ, Kavoussi LR, Novick AC, Partin AW, eds. Campbell-Walsh Urology. Philadelphia, PA: Saunders 2007: 907-908

8. Germà-Lluch JR, Garcia del Muro X, Maroto P et al. Clinical pattern and therapeutic results achieved in $1490 \mathrm{pa}-$ tients with germ cell tumours of the testis: the experience of the Spanish Germ-Cell Cancer Group (GG). Eur Urol 2002; 42(6): 553-563. doi: 10.1016/s0302-2838(02)00 439-6.

9. Schefer H, Mattmann S, Joss RA. Hereditary persistence of alpha-fetoprotein. Case report and review of the literature. Ann Oncol 1998; 9(6): 667-672. doi: 10.1023/a:1008243311122.

10. Thompson WG, Gillies RR, Silver HK et al. Carcinoembryonic antigen and alpha 1-fetoprotein in ulcerative colitis and regional enteritis. Can Med Assoc J 1974; 110(7): 775-777

11. Doherty AP, Bower M, Christmas TJ. The role of tumour markers in the diagnosis and treatment of testicular germ cell cancers. Br J Urol 1997; 79(2): 247-252. doi: 10.1046/j.1464-410x.1997.27517.x.

12. Milose JC, Filson CP, Weizer AZ et al. Role of biochemical markers in testicular cancer: diagnosis, staging, and surveillance. Open Access J Urol 2012; 4: 1-8. doi: 10.2147/OAJU.S15063

13. Reilley MJ, Pagliaro LC. Testicular choriocarcinoma: a rare variant that requires a unique treatment approach. Curr Oncol Rep 2015; 17(2): 2. doi: 10.1007/s11912-0140430-0.

14. Oldenburg J, Fosså SD, Nuver J et al. Testicular seminoma and non-seminoma: ESMO Clinical Practice Guidelines for diagnosis, treatment and follow-up. Ann Oncol 2016; 24(6): vi125-vi132. doi: 10.1093/annonc/mdt 304

15. Gilligan T, Lin DW, Aggarwal R et al. Testicular Cancer, version 2.2020, NCCN Clinical Practice Guidelines in Oncology. J Natl Compr Canc Netw 2019; 17(12): 1529-1554. doi: 10.6004/jnccn.2019.0058.

16. Laguna MP, Albers $P$, Albrecht $W$ et al. EAU guidelines on testicular cancer; 2019. [online]. Available from: https://uroweb.org/wp-content/uploads/EAU-Guidelines-on-Testicular-Cancer-2019-1.pdf.

17. Morris MJ, Bosl GJ. Recognizing abnormal marker results that do not reflect disease in patients with germ cell tumors. J Urol 2000; 163(3):796-801. 